\title{
SMART ENVIRONMENTAL POLICY WITH FULL-COST PRICING
}

\author{
Nancy Olewiler \\ School of Public Policy Simon Fraser University
}

\section{SUMMARY}

Canada's natural capital - its resources, ecosystems and wildlife - are indispensable to the productivity of industry. Despite this, both the public and private sectors have failed to adequately factor in the consequences of production and consumption on the natural environment. There is a growing need for full-cost pricing, a system that adjusts market prices to reflect not only the direct costs of good and services, but also their impact on this country's natural capital. As this paper argues, the onus is on the federal government to create the conditions for full-cost pricing to succeed. Ottawa needs to eliminate energy subsidies (to producers and consumers), implement full-cost pricing on air contaminants and greenhouse gases and encourage projects at the provincial and municipal levels that adopt that methodology. The benefits include productivity gains; potentially billions in savings for consumers, businesses and governments; a strong environment supporting sustainable industries; and simplified tax systems. In surveying past and existing federal initiatives and missed opportunities in previous budgets, this paper assesses costs and consequences, arguing that a healthy environment is synonymous with a healthy economy, and providing hard data to back up that conviction. With Budget 2012 just around the corner, the time is ripe for the Harper government to introduce full-cost pricing, and guarantee Canada a brighter future. 


\section{INTRODUCTION AND SUMMARY}

Canada's natural capital is vital to the productive capacity of its industry, the sustainability of the environment and our quality of life. Natural capital consists of Canada's stocks of renewable and non-renewable natural resources (fossil fuels, minerals, forests, fish, soils), environmental resources (atmosphere, water), land and ecosystems. Ecosystem goods and services are the flow of inputs from natural capital used along with produced capital and labour to produce and sustain the economy's goods and services and our wellbeing. This paper examines three areas of environmental policy development the federal government could introduce over the next few years that support its current objectives without increasing the deficit. The focus in this paper is on federal initiatives rather than the complex scope of federal and provincial environmental policy. The analysis and recommendations offered can apply to the provincial level as well. Leadership on the part of the federal government may help facilitate similar actions by the provinces, particularly in contentious areas of policy development such as energy-related subsidies.

The policy developments suggested in this paper focus on the concept of pricing natural capital based on its full costs, not just private costs. Full-cost pricing ${ }^{l}$ in the context of ecosystem goods and services means that we find ways to adjust market prices to reflect not only the direct costs of production of goods and services, but the impact production and consumption have on the quantity and quality of natural capital. Markets fail to fully price ecosystem goods and services when they have attributes of a public good or bad. With public goods, people can enjoy the benefits of consuming the services of, for example, an urban natural area without directly paying for it. A public bad or negative externality can arise in the production and/or consumption of goods. An example is the air pollution and greenhouse gases that emanate from fossil fuel processing and combustion. An additional example of failure to use full-cost pricing occurs when regulated prices do not reflect the impact on ecosystems. For example, water prices for household, industrial, or agricultural use typically reflect the operating and capital costs of delivering the water, but do not include the impact of water withdrawals on ecosystems that can include loss of biodiversity, impacts on drainage and storm runoff, and depletion of surface and groundwater. The costs to society from "ignoring or undervaluing natural capital in economic forecasting, modelling and assessments can lead to public policy and government investment decisions that exacerbate the degradation of soils, air, water and biological resources and thereby negatively impact a range of economic and social objectives." ${ }^{2}$ These negative impacts can include the loss of natural capital services such as "water purification, waste assimilation,

\footnotetext{
I See, for example, TEEB ((2010) "The Economics of Ecosystems and Biodiversity: Mainstreaming the Economics of Nature: A synthesis of the approach, conclusions and recommendations of TEEB." Hosted by the United Nations Environment Program) and the references therein for a thorough discussion of the principles of full-cost pricing as well as examples and methods of pricing. An example of a more technical paper is Boyd, J. and S. Banzhaf (2006). "What are Ecosystem Services? The Need for Standardized Environmental Accounting Units," Resources for the Future, RFF Discussion Paper 06-02, January 2006. Washington, DC. Freeman, A.M. (2003). The Measurement of Environmental and Resource Values. Washington, DC: Resources for the Future is an example of an introductory economics textbook that covers valuation. A book that illustrates how decision-making would be enhanced with fullcost pricing of ecosystem goods and services is National Research Council (2004) Valuing Ecosystem Services: Toward Better Environmental Decision Making. Washington, DC: National Academy of Sciences.

2 TEEB (2010) op. cit. P. 10
} 
cleansing of the atmosphere, mitigation of greenhouse gas emissions, flood prevention, soil retention, fertility enhancement, alternative recreational services and much more."”3 Moreover, depletion of natural capital often leads to the need to invest in substitute infrastructure that may be more expensive than the costs of protecting natural capital. An example is the need to construct or enhance water treatment facilities when the waste assimilation services of wetlands and forests are lost to urban development. Failure to account for the impact of our investment, consumption, and production actions on natural capital is also an equity issue. As TEEB notes "poorer households, in particular in rural areas, face disproportionate losses from the depletion of natural capital due to their relatively high dependence on certain ecosystem services for income and insurance against hard times." ${ }^{4}$ Many communities in rural regions of Canada are highly dependent on natural capital for their livelihoods. Intergenerational equity implies that we should leave our children, grandchildren, and future generations a stock of natural capital that allows them to afford the same quality of life as we have obtained. Incorporating the total value of ecosystem goods and services into decision-making helps ensure the economy is using its productive resources in the highest uses and distributes them fairly both today and into the future.

Areas where movement to full-cost pricing of ecosystem goods and services can help improve economic efficiency and environmental quality, and not increase the federal deficit include:

1. Eliminate subsidies to the natural capital sectors where marginal effective tax rates are substantially below those of other sectors and where consumer subsidies are shown to be relatively ineffective with low returns per dollar spent. These reforms will level the playing field across sectors, reduce inefficiencies and recover foregone tax revenue. Act on commitments made to the G-20 to phase out energy subsidies and thus simplify the corporate tax system and level the playing field across sectors. This includes subsidies to renewable as well as non-renewable energy sources, subsidies to mineral production, and producer and consumer subsidies. Elimination of subsidies may lower federal expenditures and/or foregone tax revenues significantly. ${ }^{5}$ Ideally, inefficient subsidies would also be phased out at the provincial level. ${ }^{6}$

3 Olewiler, N. (2004) “The Value of Natural Capital in Settled Areas of Canada," Ducks Unlimited Canada and The Nature Conservancy of Canada. P. 1.

4 TEEB (2010) op. cit.

5 It is difficult to get a precise estimate of the amount of revenue gain to the federal government because estimation requires analysis of impacts at the federal and provincial levels, as well as behavioural responses induced by the policy changes. I have not quoted estimates in the literature as many do not fully account for factors such as provincial royalty systems and general equilibrium impacts.

6 See Commission on the Reform of Ontario's Public Services (2012) "Public Services for Ontarians: A Path to Sustainability and Excellence," Queen's Printer for Ontario. Accessed at: http://www.fin.gov.on.ca/en/reformcommission/chapters/report.pdf, on 22 February 2012 (the Drummond Report). It also supports the removal of energy subsidies. 
2. Implementation of full-cost pricing of air contaminants and greenhouses gases. Canada's federal policies currently focus on regulations to limit the quantity of emissions of air contaminants and greenhouse gases. Decades of economic analysis show that performance and technology-based standards can achieve environmental goals, but at costs that are typically above those of a full-cost pricing method such as emissions taxes or a cap and trade system. Some provinces currently have pricing policies (e.g., BC's carbon tax), but also have complex systems of regulations. Compliance costs for industry could be lowered with a more unified national system that replaces hosts of regulations with pricing instruments. While my focus is on federal policy, the hope is that leadership on the part of the federal government would provide an incentive for greater policy harmonization across the country. It is beyond the scope of this paper to predict the net impact of the removal of inefficient regulations combined with pricing policies that provide more flexibility to industry, but evidence from other countries suggests that total compliance costs to industry would decrease and greater progress to environmental targets achieved. ${ }^{7}$

\section{Partner with provinces and municipalities to help coordinate and provide funding to} projects that apply the concepts of full-cost pricing. One way to explore the use of full-cost pricing is to coordinate and provide some funding for pilot programs that introduce full-cost pricing. Two potential candidates are: (a) coordinate with provinces to provide payments for ecosystem goods and services on agricultural lands as means of reducing the need for built infrastructure to protect and enhance natural capital (particularly air and water resources); and (b) partner with municipalities who want to explore the use of road pricing to optimize road use, reduce congestion, and use the revenues to fund public transit. The first is an example of full-cost pricing on private lands where the benefits of protecting natural capital accrue to society, not just the landowner. The second is an area where more direct pricing of a shared public good would improve the efficiency of road use and improve air quality. These measures can help stimulate the economy and protect the environment. Funding can come from revenues gained from the reduction in subsidy programs.

This paper first provides rationales for the recommended directions, and then briefly surveys environmental initiatives expressed in the federal budgets from 2007 to 2011 to provide a federal policy baseline. I look at the areas where the policy baseline does or does not efficiently and equitably achieve its environmental goals to set the stage for the recommendations listed above. The paper concludes with a summary of the missed opportunities and policy directions that could be implemented in upcoming federal budgets.

7 See later sections of the paper for evidence. An example is the amendments to the Clean Air Act in the United States, where a cap and trade system covering sulphur dioxide emissions from electricity-generating power plants was introduced, and environmental targets achieved more quickly than predicted with total compliance costs to industry well below those imposed by the previous regulations. 


\section{BUILDING CANADA'S NATURAL CAPITAL IS CORE TO ECONOMIC GROWTH AND WELLBEING}

Canada's natural capital wealth provides essential inputs to the production of all our goods and services. Our lands, atmosphere and water are essential to economic activity and our quality of life. Conventional measures of productivity typically do not take the quality of natural capital inputs into account and hence, can understate productivity growth, especially when we consider environmental attributes. Several studies illustrate the potential impact investing in sustaining or improving natural capital can have on productivity. Zivin and Neidell's examination of agricultural workers in the US found that a 10ppb reduction in ground-level ozone increased worker productivity by 4.2 percent. $^{8}$ Ostblom and Samakoulis investigated losses in productivity due to health effects of air pollution, ${ }^{9}$ and Mazzanti and Zoboli, using panel data for the Italian economy from 1990-2002, found that emissions intensity of production (emissions per unit value added) was negatively correlated with labour productivity. ${ }^{10}$ The Clean Air Act regulations in the US electric utility sector stimulated innovation and investment in new technologies and reduced sulphur dioxide levels, also leading to labour productivity growth. Harchaoui and Lasserre estimated that reductions in GHG emissions would increase productivity growth in 37 Canadian industries by 0.5 percent annually. ${ }^{11}$ These examples illustrate that full-cost pricing of natural capital can improve economic performance and stimulate innovation, and conversely, higher emission levels of air contaminants and GHGs can impede investment and growth. Full-cost pricing of fossil fuels can also reduce the need for subsidies to alternative energy sources or energy-saving technologies by increasing the return to investment on them. Any regulatory change imposes costs and it is important to net out the losses from the gains with careful study. One such example is the US Acid Rain program with its Clean Air Act Amendments. Carlson et al. estimated the change from technology standards to the cap and trade allowance market resulted in a net gain of approximately $\$ 750$ million per year (1995 US dollars), ${ }^{12}$ which represents a reduction of about 40 percent in annual compliance costs. ${ }^{13}$

8 Zivin, J. and M. Neidell (2011) "The Impact of Pollution on Worker Productivity," National Bureau of Economic Research Working Paper 17004. Accessed at http://www.nber.org/papers/w17004 on February 22, 2012. Ostblom, G. And E. Samakovlis (2004).“Costs of Climate Policy when Pollution Affects Health and Productivity, A General Equilibrium Analysis applied to Sweden,” Stockholm: National Institute of Economic Research, Working Paper No. 93, December 2004. Accessed at: http://konj.se/download/18.70c52033121865b13988000100744/WP_93.pdf, 24 February 2012.

10 Manzzanti, M. and R. Zoboli (2007) "Environmental Efficiency, Emission Trends and Labour Productivity: TradeOff or Joint Dynamics? Empirical Evidence Using NAMEA Panel Data," Italy: The Fondazione Eni Enrico Mattei Note di Lavoro Series Index, Nota Di Lavoro 40.2007 April 2007. Accessed at: http://ageconsearch.umn.edu/bitstream/9320/1/wp070040.pdf, February 23, 2012.

11 Harchaoui, T.M. and P. Lasserre. 2002 “Assessing the Impact of Greenhouse Gas Emissions on Canada's Productivity Growth, 1981-1996 - An Experimental Approach,” Economic Analysis Research Paper Series 11F0027MIE2002009. Analytical Studies Branch. Ottawa: Statistics Canada.

12 Carlson et al. (2000). "SO2 Control by Electric Utilities: What are the Gains from Trade?" Journal of Political Economy, Vol. 108, No. 6: 1292-1326.

13 The estimate is based on several models of what compliance costs would be if the standards had continued under different development of technology (for gas scrubbers), but looked at the actual as opposed to the hypothetical performance of the allowance market. The market did not reach its full efficiency, so the estimate reflects real world market condition as opposed to hypothetical design efficiency. Subsequent analysis of this work confirms the robustness of their calculations. See Ellerman, A.D. (2003) "Ex Post Evaluation of Tradable Permits: The U.S. SO2 Cap-and-Trade Program," Center for Energy and Environmental Policy Research, MIT, 03-003 Working Paper, February 2003. 
Another way to illustrate the impact of degradation of natural capital is to look at the losses in economic activity and wellbeing of Canadians from poor environmental quality. Air pollution provides an example of the losses that occur. Table 1 shows the health-care costs and loss of quality of life from air pollution in Canada for sample years, as estimated by the Canadian Medical Association in 2006. The numbers are significant even if one ignores the quality of life and loss of life estimates. The costs include premature mortality, but not morbidity nor damages from air pollution to agriculture, forests, materials, wildlife and ecosystems. While $\$ 8$ billion in 2008 is a small share of total GDP, it represents losses in economic productivity that could be avoided or reduced if air quality improved. Dollars also cannot fully represent the impacts on families of premature mortality. ${ }^{14}$

TABLE 1: DAMAGES FROM ACUTE PREMATURE MORTALITY DUE TO AIR POLLUTION, 2006, CONSTANT \$)

\begin{tabular}{|l|r|r|r|}
\hline \multirow{2}{*}{} & \multicolumn{3}{|c|}{ Damages for Illustrative Years (\$ Millions) } \\
\cline { 2 - 4 } & $\mathbf{2 0 0 8}$ & $\mathbf{2 0 1 5}$ & $\mathbf{2 0 3 1}$ \\
\hline Lost Productivity & $\$ 688$ & $\$ 721$ & $\$ 765$ \\
Health-Care Costs & 438 & 485 & 614 \\
Quality of Life & 379 & 410 & 487 \\
Loss of Life & 6,552 & 7,905 & 11,836 \\
Total & $\mathbf{8 , 0 5 8}$ & $\mathbf{9 , 5 2 2}$ & $\mathbf{1 3 , 7 0 2}$ \\
\hline
\end{tabular}

Source: Canadian Medical Association (2008) “National Illness Costs of Air Pollution," Technical Report, August 2008.

We do not have good estimates of the costs of poor water quality (see Table 3 and Figure 1 below). But a host of concerns exist about Canada's fresh water supplies that include: eutrophication from fertilizers and urban storm runoff, inadequate sewage treatment, waterborne disease outbreaks, contamination of water from discarded pharmaceuticals, chemical contamination (nitrates, pesticides), contamination from fossil fuel extraction and production, and other industrial chemical and biological contaminants, inadequate water supply due to inefficient water use (e.g., subsidized irrigation and insufficient pricing of water use in oil sands). Water quality on many First Nations reserves is below health and environmental guidelines and a source of disease and poor health. Deficiencies in water treatment and delivery systems due to ageing and deteriorating environmental infrastructure in urban areas are a growing cost burden to municipalities and industry, as well as a health concern. Because we have no national estimates of the full extent of poor water quality or inadequate water supply in Canada, it is difficult to provide an estimate of the aggregate costs to society and the economy.

Loss of our natural areas, particularly acute around our cities and towns, reduces the ecosystem goods and services from natural capital and requires production of substitutes (when substitutes exist). The money spent on these substitutes could have been used to invest in other productive activities. Loss of wetlands lowers water quality, requiring a higher level of water treatment infrastructure; loss of forests reduces absorption of runoff from rainfall requiring more dykes or other means of water retention, loss of natural areas reduces GHG sequestration requiring more technological substitutes to capture and store carbon. These losses lower the quality of life as well as adversely affect sectors dependent on EGS - natural resources, tourism and agriculture. We have no good estimates of the annual costs of these losses.

\footnotetext{
14 Some may argue that premature mortality is beneficial to publicly provided health care because the people who die will not put a future burden on the health-care system. However, if the largest share of health-care costs accrue during the few years of a person`s life, then their age of death is less relevant than the cause of death and type of health-care expenditures incurred.
} 
The following section looks at the environmental initiatives of recent federal budgets, followed by an assessment of their efficiency and effectiveness. This lays the foundation for the recommended new directions that the federal government could consider in moving forward to help sustain Canada's natural capital and build a more robust economy.

\section{ENVIRONMENTAL INITIATIVES IN THE FEDERAL BUDGETS: 2007-2011}

A clean and healthy environment is one of the government of Canada's economic goals set in recent budgets. The others - strong economic growth, income security and employment, a fair and secure marketplace, and promoting innovation and a knowledge-based economy - are also dependent on a sustainable environment, a dependency that deserves more recognition in government objectives; it is the economy and the environment. The budgets for 2007 to 2009 identified a number of environmental initiatives that could help build and sustain a more resilient environment and boost Canadian productivity. These cover three main areas: (1) the energy sector - GHG emissions, clean air, and green energy; (2) clean water and land; and (3) green infrastructure. Budgets for 2010 and 2011 added no new substantive environmental initiatives; returning the economy to prosperity took precedence. Key features of the 2007 to 2009 budgets are noted below. With a few exceptions, most of the initiatives provided shortterm incentives or one-time money or funding of limited duration rather than policies that either directly regulated activities that degraded natural capital or priced environmental externalities. No innovative environmental initiatives emerged.

Greenhouse Gas Emissions (GHGs), Clean Air, and Green Energy: Canada does not have binding regulation limiting GHG emissions or air contaminants (sulphur and nitrogen oxides, particulate matter, ozone, carbon monoxide). Policy direction is provided by non-binding guidelines. The current GHG reduction targets are to reduce emissions 17 percent below their 2007 levels by 2020. Guidelines for ambient air quality levels for air contaminants develop hourly to yearly targets. The 2007 and 2008 budgets saw the introduction of a number of ecoENERGY programs. The Clean Energy Fund - \$1 billion over five years - was introduced in the 2009 budget to support "the development and demonstration of technologies, including large-scale carbon capture and storage projects." 15 Policies introduced thus far are largely focused on funding programs to develop technologies to sequester carbon and clean coal (e.g., the $\$ 1.5$ billion Canada ecoTrust for Clean Air and Climate Change); R\&D for fuelefficient vehicles; subsidies for investments to reduce energy consumption and for renewable energy development; and regulations such as fuel efficiency standards for cars and light trucks. Subsidies to industry included: extension of accelerated capital cost allowance (ACCA) to industries that invest in equipment that improves energy efficiency and equipment acquired prior to 2020 for renewable energy including wave, solar, tidal and waste-to-energy technologies; extended ACCA to stationary equipment in clean energy generation systems in 2010; and a $\$ 2$ billion (over seven years) program to subsidize the production of renewable fuels. Consumers received subsidies of up to $\$ 2000$ to purchase a fuel-efficient vehicle (a fund of $\$ 160$ million over two years that also included a levy on fuel-inefficient vehicles) and a payment for scrapping an older fuel-inefficient vehicle (through the fund of $\$ 36$ million from 2008 to 2010). There were also subsidies to retrofit homes to improve energy efficiency and

15 “Canada's Economic Action Plan,” Government of Canada (2009) Budget. P. 179. 
encourage the development and installation of new energy products, and foster improved techniques in home construction and renovation. ${ }^{16}$ These subsidies were to end in 2011, but the 2011 budget extended the program to March 31, 2012. However the program has now reached its goal of registering 250,000 homeowners, so will no longer accept any additional registrants. The maximum total grant is $\$ 5000$ with subsidy amounts specified for a list of eligible investments that range from $\$ 40$ for five electronic thermostats for electric baseboard heat to $\$ 4375$ for installation of a ground or water source energy-earth heating system (often referred to as geothermal). Conditions for eligibility were prescriptive, requiring a pre-retrofit energy assessment of the whole dwelling unit by a licensed service organization as well as a postretrofit inspection. Budgets over the five years continued the tax credit introduced in 2006 to transit users who held a minimum of a monthly transit pass. Information campaigns were another feature in the ecoEnergy programs.

A National Water Strategy was announced in the 2007 budget with goals to improve protection of drinking water and decrease untreated wastewater. These were time-limited programs to remove contaminated sediments in major water bodies such as the Great Lakes, Lakes Simcoe and Winnipeg and funding of programs to protect oceans, help prevent pollution along the coasts, support fisheries research and help improve drinking water and wastewater treatment on First Nations. Total funding for these programs was less than $\$ 100$ million for the period they ran (typically less than three years).

Clean Land: Solid waste disposal and encouraging efficient land use comprised the goals of this program, but little has been done to achieve these goals. Most of the funding was allocated to the protection of ecologically sensitive land in the form of protected areas and species (e.g., $\$ 225$ million for the Nature Conservancy of Canada to conserve ecologically sensitive land in southern Canada and \$30 million for sustainable land and resource management development in the Great Bear Rainforest, \$5.5 million for a national park in Labrador and \$110 million for the Species at Risk Act).

Green Infrastructure: Budgets prior to 2009 provided funding for provincial and municipal public transit capital investment, but these were typically time-limited. For example, the 2008 budget allowed for a $\$ 500$ million trust to be allocated on a provincial-territorial per-capita basis for public transportation, provided public commitments to a project were made before March 31, 2008 and funds drawn down over the subsequent two years. A big change came with the 2008 budget, where the government made permanent a transfer of $\$ 2$ billion annually to the provinces to be spent at the municipal level to support sustainable environmental infrastructure projects - the Gas Tax Fund. These projects could include public transit, water and wastewater treatment, community energy systems and solid waste treatment. The funds come from the federal fuel excise tax on motor vehicles. The transfer of a share of the gas tax was originally part of the 2006 budget, but it was the 2009 budget that fixed the amount and made it permanent. The 2009 budget also introduced the Green Infrastructure Fund $-\$ 1$ billion over five years - but it was initially vague on what the Fund would cover. The only example of sustainable infrastructure provided at that time was energy transmission lines that "will contribute to improved air quality and lower carbon emissions.",17

\footnotetext{
16 Government of Canada (2010) Budget. "Leading the Way on Jobs and Growth."

17 Government of Canada (2009) op. cit. P. 144.
} 
Infrastructure $\mathrm{Canada}^{18}$ now defines green infrastructure projects as those that promote cleaner air and water and reduce GHGs. All projects must be cost-shared with provincial, territorial, and/or municipal governments. Eligible projects fall into the following categories: wastewater infrastructure, green energy generation and transmission, solid waste, carbon transmission and storage. The fund is now fully subscribed, so no new projects can apply. The total budget was reduced by $\$ 215$ million, with $\$ 170$ million transferred to other programs and $\$ 45$ million cut as a result of the government's Strategic Review process. An example of one funded project illustrates one potential the program had. BC's Northwest transmission line is a 335-kilometre line into a remote region of the province previously served by diesel generation. The $\$ 400$ million line will allow households and industry in the region access to BC's largely hydroelectric system as well as provide renewable electricity generators (wind, small hydro, biomass) located in the region access to markets. Without this sort of investment, these renewable sources, often located far from existing grids, could not get their electricity to the market and hence, reduce the potential for green energy development. BC's line is the only major transmission line funded in the program. Finally, the $\$ 33$ billion major infrastructurespending program (over seven years) of the 2007 budget could include green infrastructure projects if they were shovel-ready, such as public transit.

Regulatory Changes. Few regulatory initiatives covering the environment were introduced under federal budgets of the past five years. The government announced early in 2008 that corporate average fuel efficiency guidelines (CAF-C) for cars and light trucks would become mandatory in 2011, and pegged at the levels set in the CAFE standards in the US. These regulations apply to new vehicles coming off the assembly line and it will thus take time for air quality improvements to reflect the greater fuel economy (and hence, fewer emissions from fossil fuel combustion). There are still a relatively small number of hybrid and other highly fuel-efficient vehicles being sold annually in Canada. Vehicles also have to be maintained by their owners to ensure optimum performance. Inspection of vehicle emissions is under provincial/municipal authority. A number of regulatory changes that affect the environment were also introduced in Budget 2009. A controversial one was the announcement of revisions to streamline regulatory approvals under the Canadian Environmental Assessment Act, Fisheries Act, and Navigable Waters Act. The stated goal of the regulatory reform was "to drive efficiencies in assessing environmental and other impacts of infrastructure projects without compromising protection of the environment." 19 In Budget 2010, the government announced it would move the responsibility for environmental assessment of large energy projects from the Canadian Environmental Assessment Agency to the National Energy Board and Canadian Nuclear Safety Commission for their respective energy sources. Under a revised Canadian Environmental Assessment Act, projects would face either a provincial or federal assessment, but not both, as was the current case. If the provincial assessment process was no less binding than the federal process, the federal process could be waived. The provision was controversial because environmental proponents feared that there would be less oversight over projects that might damage the environment than in the past. These changes were also a surprise to the environmental community because of the lack of consultation.

\footnotetext{
${ }^{18}$ See http://www.infrastructure.gc.ca/prog/gif-fiv-eng.html

19 Government of Canada (2009) op. cit.
} 


\section{IS CANADA EFFICIENTLY AND EFFECTIVELY ACHIEVING ITS ENVIRONMENTAL GOALS?}

Using the framework for environmental policies as set out by the budgets over the past five years, I ask if the policies are efficient and cost-effective, and whether they have helped us achieve environmental goals.

Progress on Environmental Goals: The Treasury Board annually examines the government's progress in meeting its policy goals. The goal of interest is a clean and healthy environment. The most recent report looks at expenditures connected to the environment and a limited set of performance indicators. ${ }^{20}$ Table 2 presents the trends in total federal spending for all ministries connected to Canada's natural capital (predominately Natural Resources Canada and Environment Canada) from 2007 to 2010 and shows that it has fallen in both absolute terms and relative to total government spending from 2007 to 2011, albeit an improvement has occurred from 2008-09 to the most recent data. ${ }^{21}$

TABLE 2: TRENDS IN TOTAL FEDERAL SPENDING ON A "CLEAN, HEALTHY ENVIRONMENT"

\begin{tabular}{|l|c|c|}
\hline Fiscal Year & \$ billions & $\begin{array}{c}\text { \% of Total Government } \\
\text { Spending }\end{array}$ \\
\hline $\mathbf{2 0 0 7 - 0 8}$ & 4.6 & 1.98 \\
$\mathbf{2 0 0 8 - 0 9}$ & 2.6 & 1.09 \\
$\mathbf{2 0 0 9 - 1 0}$ & 3.3 & 1.20 \\
$\mathbf{2 0 1 0 - 1 1}$ & 3.7 & 1.37 \\
\hline
\end{tabular}

Sources: Treasury Board (2010), data from Figure 2.9, p. 34. Treasury Board (2011), data from http://www.tbssct.gc.ca/ppg-cpr/ps-dp-eng.aspx?Rt=1049\&Pa=1230\&Gc=1644, accessed October 3, 2011.

Table 3 presents environmental performance indicators for air and water quality, biodiversity and greenhouse gases (GHGs). Many of these indicators were presented in the Treasury Board's assessment of the federal government's performance. As the table indicates, the trends are mixed. There has been improvement in average ambient air quality with respect to sulphur dioxide, but particulate matter, ground-level ozone and volatile organic compounds remain a concern, as does water quality, biodiversity and GHG emissions. Figure 1 illustrates that nitrates in water are a growing concern over time, while phosphates are undergoing a net decline. Suffice it to say that the indicators do not paint a picture of widespread environmental health and some Canadians, notably First Nations residents, have extremely poor water quality. The GHG indicator is particularly concerning because as the previous section illustrated, the vast majority of

${ }^{20}$ Report of the Treasury Board of Canada (2010) Canada's Performance 2009-2010, Government of Canada's Contribution. Accessed at: http://www.tbs-sct.gc.ca/reports-rapports/cp-rc/2009-2010/cp-rc-txt-eng.asp\#clean, on 12 November 2011.

21 Due to the different ways of presenting the data from year to year, it is difficult to disaggregate into specific government initiatives. To get a fulsome picture of total government spending on environmental initiatives, provincial and municipal data is also needed, an exercise beyond the scope of this paper. Recent data from the Parliamentary Budget Officer (see the Expenditure Monitors available at: http://www.parl.gc.ca/PBO-

DPB/documents/Expenditure_Monitor_2011Q1_EN.pdf , and similarly for other quarters) identifies reductions in grants and contributions to Environment Canada which fell by 82 percent in the first quarter of fiscal year 2011-12 compared to Q1 of the previous year, and 69 percent in Q2 of 2011-12 compared to the previous year. No specific explanation was provided to the PBO for the reductions, nor is a dollar amount provided. How these cuts affect programs described in this paper is unknown, but they likely will affect some aspects of environmental protection (e.g., the elimination of atmospheric ozone monitoring in the Arctic). 
environmental initiatives in the budgets were targeted at reducing energy consumption from fossil fuels. Over the time period for which data is available, while energy intensity (e.g., gigajoules of energy used per dollar of output) has generally fallen, energy production and consumption rose substantially from 2000 to 2008 . The next section discusses the role policy may have played. Overall, the trend in environmental quality is at best, ambiguous.

\section{TABLE 3: ENVIRONMENTAL PERFORMANCE, 2000-2008}

\begin{tabular}{|c|c|}
\hline Indicator & Percent or level change $\mathbf{2 0 0 0 - 2 0 0 8}$ \\
\hline Ambient air quality: ground-level ozone & Rose $11 \%$ \\
\hline $\begin{array}{l}\text { Ambient air quality: particulate matter, } \\
2.5 \text { microns }\end{array}$ & $\begin{array}{l}\text { Relatively no change at a level of around } \\
10 \text { micrograms/cubic meter }\end{array}$ \\
\hline $\begin{array}{l}\text { Ambient air quality: volatile organic } \\
\text { compounds }\end{array}$ & $\begin{array}{l}\text { Fell from approximately } 160 \text { parts per billion (ppb) to } \\
125 \text { ppb } 2000-2002 \text {, then rose to } 135 \text { ppb in } 2003 \text { and } \\
\text { fluctuated around this level to } 2008\end{array}$ \\
\hline Ambient air quality: sulphur dioxide & Fell by close to $50 \%$ from $4 p p b$ to 2 ppb \\
\hline Water quality & $\begin{array}{l}\text { Approximately } 40 \% \text { of } 153 \text { sampled sites (2005-2007) rated } \\
\text { very good to excellent, } 60 \% \text { rated fair, marginal, to poor. }\end{array}$ \\
\hline Biodiversity & $\begin{array}{l}259 \text { species at risk reassessed in June } 2010 \text { found } 13 \% \\
\text { improved, } 20 \% \text { declining, } 61 \% \text { no change }\end{array}$ \\
\hline Greenhouse gas emissions & Rose from 469 megatonnes $\mathrm{CO}_{2}$ equivalent to $597 \mathrm{MtCO}_{2}$-e. \\
\hline
\end{tabular}

Sources: Treasury Board (2010), Environment Canada, National Air Pollution Surveillance Network, accessed at www.ec.gc.ca/rnspa-naps/Default.asp?lang _ En\&n _ 5COD33CF-1 on November 13, 2011.

FIGURE 1: NUMBER OF SITES WITH INCREASING, DECREASING, OR CONSTANT LEVELS OF NITRATES AND PHOSPHORUS IN WATER SUPPLIES, IN 1990 VERSUS 2006

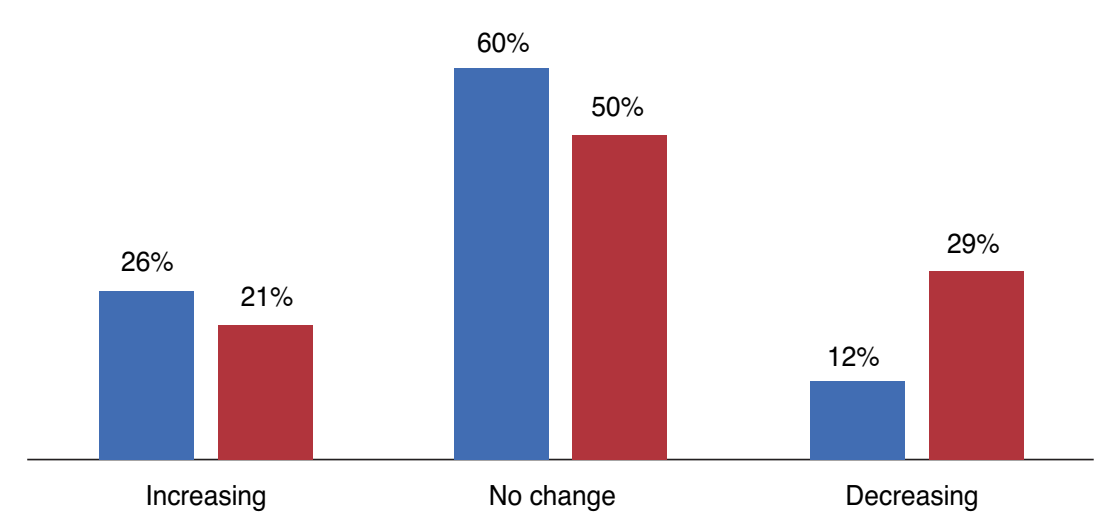

Number of Sites Nitrate-nitrite

Number of Sites Phosphorus

Source: Data assembled from federal and federal-provincial water quality monitoring programs and analyzed by Environment Canada. Accessed at: www.ec.gc.ca/ indicateurs-indicators/default.asp?lang _ En\&n_68DE8F72-1, on November 13, 2011. 
Environmental Infrastructure Investments: The Gas Tax Fund (GTF) can improve environmental quality if the funds are used to improve public transit and investment in environmental infrastructure. Public transit reduces congestion on roads, saves people time and improves goods' movement, which helps reduce the cost of delivering freight across the country. Getting people out of their cars also reduces air pollution and GHG emissions. A full accounting of expenditures to the present is not yet available, but Infrastructure Canada reports that over the period 2005-2008, approximately $\$ 1.39$ billion dollars of a total $\$ 1.8$ billion was spent on public transit, solid waste and water and wastewater investments, illustrating the value of the program to many cities and towns across the country. ${ }^{22}$ The GTF can thus be a vital contributor to protecting and enhancing environmental infrastructure, but it is also important to assess the effectiveness of the fund - does it yield projects that would satisfy a robust full social benefit and cost accounting, and not just funds that have to be spent? The GTF, if the funds are efficiently and effectively spent to improve environmental quality, can be seen as a payment for ecosystem services - the payment is the tax on vehicle gasoline and diesel fuel use. The link would however be more direct if the federal fuel excise tax were based on emissions of air contaminants and GHGs. ${ }^{23}$ The Green Infrastructure Fund (GIF) has now committed all its available funding as noted above, but actual spending continues to ramp up as estimated in a report by the Office of the Parliamentary Budget Officer. ${ }^{24}$ According to Infrastructure Canada's web page, ${ }^{25}$ there are 17 projects announced to date, of which the federal government's planned expenditures total $\$ 130$ million for the $\mathrm{BC}$ transmission line, $\$ 71$ million for upgrades to a hydroelectric facility in the Yukon, a maximum of \$254.5 million for nine wastewater treatment investments (eight in Ontario and one in Manitoba), and \$170.8 million for various types of garbage-to-energy projects, all of which are in Quebec.

\section{Are the Environmental Policy Priorities over the Past Five Years Efficient and Cost-Effective?}

The federal government assessed several of its programs targeted at achieving a clean and healthy environment. Infrastructure Canada's assessment of the GTF as of 2008 found it delivered projects with low administrative costs, got the funds to projects quickly and targeted environmentally appropriate projects. The question of whether the individual projects were costeffective and whether resources were allocated efficiently requires detailed analysis at the provincial and municipal level. Estimates of cost efficiency are difficult to obtain. Transport Canada provides some estimates of the cost effectiveness of programs in terms of GHG emission reductions. ${ }^{26}$ Table 4 presents the results as cited in the report. Note that there is huge variation in the cost per tonne reduced from quite low levels to costs per tonne well above any of the current taxes or implicit prices per tonne of carbon. Indeed, the top two are well above what the GHG models from sources such as the National Round Table on the Environment and

\footnotetext{
22 http://www.infrastructure.gc.ca/pd-dp/eval/nse-esn/nse-esntab08-eng.html, accessed November 14, 2011.

23 See Mintz, J. and N. Olewiler ((2008) "A Simple Approach for Bettering the Environment and Economy: Restructuring the Federal Fuel Excise Tax," Ottawa: Sustainable Prosperity) for a proposal to restructure the federal fuel excise tax.

24 http://www.parl.gc.ca/PBO-DPB/documents/Supplementary_Estimates_B_EN.pdf, accessed November 15, 2011. At the time of that report, actual and planned expenditures totalled less than $\$ 100$ million.

25 http://www.infrastructure.gc.ca/prog/gif-fiv-eng.html, accessed February 21, 2012.

26 Transport Canada (2011). "Evaluation of the Clean Transportation Theme of the Clean Air Agenda," July 2011. Accessed at http://www.tc.gc.ca/eng/corporate-services/des-reports-829.htm on November 12, 2011.
} 
Economy say are needed to obtain significant reductions in GHG emissions. ${ }^{27}$ The most inefficient programs, the ecoAUTO rebate program and the vehicle scrappage program, are outright subsidies - paying people who buy a fuel-efficient vehicle or scrap a gas guzzler. The efficient programs, ecoFREIGHT and ecoTECHNOLOGY for example, were not outright subsidies, but relatively low-cost information programs (e.g., videos and webinars) that helped industry reduce its fuel consumption and learn about alternative technology and practices. EcoMOBILITY is another relatively low-cost program that collates and communicates best practices on travel-demand management to transportation planners and municipalities. However, it should be noted that it is challenging to accurately identify the GHG reductions that result specifically from information and outreach programs without confounding effects. The next section looks more in depth at why energy subsidy programs are likely to be inefficient - they fail to reach their targets or do so at high cost.

\section{TABLE 4: COST EFFECTIVENESS OF TRANSPORT PROGRAMS TO REDUCE FOSSIL FUEL ENERGY CONSUMPTION, COSTS} PER TONNE OF GHG EMISSION REDUCTIONS

\begin{tabular}{|l|c|c|c|}
\hline \multicolumn{1}{|c|}{ Program } & $\begin{array}{c}\text { Total Expected } \\
\text { Discounted Reductions } \\
\text { to 2025 (Mt) }\end{array}$ & $\begin{array}{c}\text { Total Program } \\
\text { Allocation } \\
\text { (undiscounted \$million) }\end{array}$ & $\begin{array}{c}\text { Discounted Program } \\
\text { Costs (\$/tonne) }\end{array}$ \\
\hline EcoFREIGHT & 12.70 & $\$ 33$ & $\$ 2.35$ \\
ecoTECHNOLOGY for vehicles & 1.71 & 15 & 7.94 \\
EcoMOBILITY & 0.98 & 10 & 9.20 \\
Marine Shore Power Program & 0.04 & 6 & 127.26 \\
National Vehicle Scrappage Program & 0.07 & 92 & $1,230.47$ \\
ecoAUTO Rebate Program & 0.06 & 264 & $4,541.57$ \\
\hline
\end{tabular}

Source: Transport Canada (2011) "Evaluation of the Clean Transportation Theme of the Clean Air Agenda," July 2011, Table 9, page 32. Accessed at http://www.tc.gc.ca/eng/corporate-services/des-reports-829.htm on November 13, 2011,

\section{The High Cost of Energy Subsidies}

\section{SUBSIDIES TO CONSUMERS}

Energy subsidies to consumers provide financial incentives to reduce energy consumption. Their rationale is that they can address the public good problem - people underinvest when the benefits of reducing one's own consumption of energy in the form of cleaner air and reductions in GHG emissions spill over to others who haven't paid for the investment. But subsidies can be inefficient and costly due to the following problems:

1. Subsidies designed to induce switching to electricity from fossil fuels (e.g., hybrid-electric vehicles, home heating) typically do not take into account the method of generating the electricity. If electricity is from existing hydroelectric dams or other forms of renewable energy, there are no air contaminants or incremental GHG emissions. If electricity is from

27 National Round Table on the Environment and the Economy (2009) Achieving 2050: A Carbon Pricing Policy for Canada. Ottawa, ON: Government of Canada. 
coal-fired plants, there are large environmental impacts. Electricity from natural gas is an intermediate case; if it substitutes for coal or diesel to generate electricity or fuel trucks, emissions fall; if it replaces or augments renewable generation, emissions rise. There is also the issue of the environmental impact of the whole supply chain from resource extraction to end-user. All energy production affects the environment; the question is which sources are the least damaging. The other issue is that many consumers do not have a choice over their source of electricity. Some provinces, e.g., Ontario and Alberta, allow some choice over supplier, but these markets thus far are fairly small with few consumers opting to pay what are typically higher rates for green electricity. Residents of the hydroelectric regulated utilities (BC, Quebec, Manitoba) have uniform rates for electricity. The impact of a federal subsidy program to induce substitution to electricity from fossil fuels will thus vary considerably in its impact across the country.

2. By lowering operating costs of energy using equipment (e.g., higher fuel efficiency vehicles), use of the equipment may actually rise and total consumption may swamp the energy efficiency per unit of consumption. This is known as the rebound effect; total emissions from energy-using goods equal emissions per unit of use times the amount of use, hence the ambiguity in the total impact. Regulations to mandate greater fuel efficiency of vehicles lower the marginal cost of driving and can lead to more kilometres traveled.

3. It is difficult to target programs to avoid attracting free riders. These are people that would have purchased the energy-saving equipment even without the subsidy. Estimates of free ridership vary considerably from a low of around 12 percent to almost 90 percent. $^{28}$ Transport Canada cites two studies examining the ecoAUTO rebate program. ${ }^{29}$ Approximately 169,000 vehicles were purchased under this program over 21 months ending December 31, 2008 and examinations of the program estimated that at least 80 percent of the buyers were free riders. Home energy retrofits are also an example of potential free ridership, although the cost of an energy audit may have been a deterrent. Another program where free riders have led to less-than-expected behavioural changes is the tax subsidization of transit pass holders. The objective of this tax expenditure was to induce more people to ride public transit. While transit ridership has gone up in a number of Canadian cities, there is anecdotal evidence that a large number of the claimants of the tax deduction had monthly or annual transit passes before the policy came into effect. Rising gasoline prices, insurance costs, and parking fees may be a more significant incentive to switch to public transit than the tax deduction. The net impact of this tax expenditure warrants more investigation.

28 Eto et al. ((2000) "Where did the Money Go? The Cost and Performance of the Largest Commercial Sector DSM Programs," Energy Journal 21(2): 23) found free ridership of 12.2 percent for commercial DSM programs, while Malm ((1996) "An Actions-based Estimate of the Free Rider Fraction in Electric Utility DSM Programs," Energy Journal 17(3): 41) estimated it at 89 percent for heating system subsidies.

29 Transport Canada (2011) op. cit. 
4. Programs may not have a high enough adoption rate to be effective in reaching targets and hence, not cost-effective. Studies of demand-side management programs in the US found that subsidies to the purchase of energy-efficient equipment led to very little take-up and may be quite expensive per unit of energy saved. Programs may also have perverse effects depending on the elasticity for demand of the energy-efficient versus inefficient good. Feebate programs have been popular in some countries and provinces. The idea is that you tax the energy-inefficient good and subsidize the efficient one. An example is auto fee-bates. If the price elasticity of demand for high-efficiency vehicles is high, people may be induced by the reduction in price to switch from public transit to a single occupancy vehicle. If demand for gas guzzlers (often high-performance, expensive vehicles) is inelastic, the tax may not dampen demand for these vehicles sufficiently to offset the increased purchase and use of the fuel-efficient vehicles. Because fee-bates apply to new vehicle sales, not used vehicles, the stock of older gas guzzling vehicles are also still on the road. Careful study of demand elasticities is thus advisable prior to the introduction of a subsidy or tax-subsidy program.

5. The market is generating better, more energy-efficient products without the need for subsidies, as producers take advantage of new technologies and materials to cut their costs of production. Homes built after 2000 are about 35 percent more energy efficient than ones built in the 1970s. Household appliances consume substantially less electricity per hour of use now than 20 years ago. Refrigerators are more than twice as efficient, washing machines almost three times and dishwashers more than three times as efficient, comparing 1990 to $2005 .{ }^{30}$ When the market is working well, subsidies are superfluous and represent expenditures that government need not make or could divert to more productive expenditures.

\section{SUBSIDIES TO PRODUCERS}

Economic arguments for subsidies to producers include infant-industry arguments and economic development (renewable and non-renewable energy sectors); uncertainty and information externalities (exploration expenses); and levelling the playing field when market prices do not reflect environmental impacts (renewable energy subsidies). Another argument is to enhance energy security (less likely a rationale in Canada - an energy superstar). While the federal government has put time limits on some of its subsidies to producers - a strategy that is useful when trying to level the playing field for start-up industries such as renewables there are other subsidies that have lasted long beyond their economic rationales, and others that were simply misguided.

In the latter category are the subsidies to biofuels, particularly corn ethanol. The 2007 budget introduced ethanol subsidies as part of $\$ 2$ billion in funding announced for biofuels. An amendment to the Canadian Environmental Protection Act in 2008 required five percent ethanol in gasoline by 2010. The net impact of producing ethanol from crops on the environment has been examined in a number of studies that look at the cradle-to-the-grave

30 Natural Resources Canada ((2009) “Improving Energy Performance in Canada," Report to Parliament under the Energy Efficiency Act for the Fiscal Year, 2007-2008) is the source for these energy efficiency estimates. 
lifecycle - all aspects of the pathway from production to combustion. The production of corn is energy and pollution-intensive, hence giving rise to the possibility that expanding corn production to produce fuel will worsen environmental quality. Moreover, there are general equilibrium effects. Regulations and subsidies increase the demand for ethanol, driving up the price of corn (and other plants as fuels). Agricultural producers who feed corn to their animals will see their costs, and hence food prices, rise. One estimate puts the potential food price increases at 1.1 percent for Canada as a result of corn ethanol subsidies. ${ }^{31}$ As was the case for some of the other energy subsidies, the policy may also be cost-ineffective. Auld estimates that the cost of reducing GHGs with the ethanol subsidies is approximately $\$ 368 /$ tonne - a price higher than many other methods of reducing GHGs. ${ }^{32}$ Ethanol is less energy-dense than gasoline or diesel. Energy density refers to the amount of energy stored in a given volume or weight of the fuel. The less dense the fuel, the more of it is required to move a vehicle a given distance. In an economic sense, a less dense fuel will be inefficient in use unless its cost per distance driven is less than that of the denser fuel. Given the large subsidies to ethanol, the appropriate comparison to determine efficiency is what the total cost per kilometre driven would be without versus with the subsidy. Estimates of the energy density of ethanol vary depending on the ethanol concentration of the motive fuel and heat values. E85 (85 percent of the fuel is ethanol) has about 75 percent of the Btu/gallon of gasoline..$^{33}$ Thus, ethanol subsidies and requirements of ethanol content are a costly policy to achieve environmental goals even if one ignores the general equilibrium and cradle-to-grave environmental impacts.

Subsidies to the non-renewable energy sector and mining have existed for many years and their rationale has long since expired. Oil, gas and mineral extraction are not infant industries in Canada. Technological developments have significantly reduced the uncertainty associated with exploration and development. It is difficult to make a case for the need to sustain the existing level of accelerated capital cost allowances (ACCA) for exploration and development. ACCA for oil sands development is being phased out, but the reductions are to the existing level of ACCA for conventional fossil fuel capital assets (30 percent). Numerous studies have made a strong argument for using economic rates of depreciation; it is time to apply this principle to energy and mineral exploration and development to level the playing field across sectors of the economy. For example, the Green Budget Coalition notes that "there is an imbalance between the tax benefits and expenditures provided to promote the virgin extraction of minerals versus much more environmentally sound alternatives of conservation and recycling of metals." ${ }^{\text {"3 }}$

McKenzie and Mintz caution that estimation of subsidies to natural resource industries should be done with care. ${ }^{35}$ Their work is based on an economic model that takes into account taxes, royalties, and other fiscal measures at the federal and provincial levels to estimate the marginal effective tax rates (METRs) on investment. Their analysis thus differs from much of the other

31 Auld, D. (2008). "The Ethanol Trap: Why Policies to Promote Ethanol as Fuel Need Rethinking," C.D. Howe Commentary No. 268, July 2008.

32 Op. cit.

33 EIA, US Energy Information Agency (2007). "Biofuels in the U.S. Transportation Sector," http://www.eia.gov/oiaf/analysispaper/pdf/tbl12.pdf, accessed 23 February 2012.

34 Green Budget Coalition (2011) "Preliminary Recommendations for Budget 2012," http://www.greenbudget.ca/2012/prelim.html accessed on November 15, 2012. P. 4.

35 McKenzie, K. J. and J. Mintz (2011), "The Tricky Art of Measuring Fossil Fuel Subsidies: A Critique of Existing Studies," University of Calgary School of Public Policy Research Paper. Sept. 2011. 
critics of subsidies in that they look at the combined effect of policies at both levels of government and do not focus solely on positive tax expenditures. They ask how a subsidy would influence the decision to invest one more dollar in exploration, development, or extraction, or produce one more tonne of material. They then compare the METRs in the natural resource sector to those of other industries in the aggregate. In their 2011 paper, the focus is on the oil and gas industry in Alberta, Saskatchewan, and Newfoundland and Labrador. Table 5 reproduces their results and shows that when looking at the combined effects of taxes and royalties, only Newfoundland and Labrador have an effective marginal tax rate that is negative. Oil and gas producers in Alberta and Saskatchewan face higher METRs than the aggregate of other sectors. If one uses the non-oil and gas sectors as a benchmark, their results do not show a subsidy to the oil and gas sectors when royalties are included in the analysis, except in Newfoundland and Labrador. When royalties are excluded, conventional oil and gas in Alberta and Saskatchewan do face lower METRs than the benchmarks. Thus, one must be careful in policy prescription when looking only at one level of government. Changes at the federal level to reduce, e.g., exploration and development write-offs without changes to provincial royalty provisions, would worsen the relative disadvantage faced by oil and gas producers in Alberta and Saskatchewan. Computation of METRs for other natural resource industries would help target where phase-out of subsidies should be focused. Given the very different royalty provisions for other natural resources, e.g., mining, and the generous provisions of other investment tax credits for some regions of Canada, e.g., the Atlantic Investment Tax Credit and exploration tax credit, suggests there is ample scope for efficiency and equity gains by phasing out these subsidies.

\section{TABLE 5: MARGINAL EFFECTIVE TAX AND ROYALTY RATES, 2011}

\begin{tabular}{|c|c|c|c|c|}
\hline \multirow[b]{2}{*}{ Oil and Gas Sector ${ }^{i}$} & \multicolumn{2}{|c|}{ Including Royalties } & \multicolumn{2}{|c|}{ Excluding Royalties } \\
\hline & Aggregate & E\&D Only & Aggregate & E\&D Only \\
\hline Alberta - conventional ${ }^{i i}$ & $29.9 \%$ & $33.4 \%$ & $6.8 \%$ & $2.6 \%$ \\
\hline Alberta - oil sands & 23.4 & -1.9 & 23.2 & -1.9 \\
\hline Saskatchewan ${ }^{i i}$ & 35.6 & 33.2 & 13.8 & -0.7 \\
\hline Newfoundland \& Labrador iii & -7.4 & -23.8 & -21.6 & -11.5 \\
\hline Non-resource Sector ${ }^{i v}$ & Aggregate & R\&D Only & & \\
\hline Alberta & 16.0 & -34.6 & & \\
\hline Saskatchewan & 21.8 & -58.7 & & \\
\hline Newfoundland \& Labrador & 8.8 & -58.8 & & \\
\hline
\end{tabular}

Note: The overall R\&D share in the non-resource sector is less than five percent while the E\&D share in the oil and gas sector is 64 percent for conventional oil and gas, 18 percent for oil sands and 79 percent for offshore drilling in Newfoundland \& Labrador.

i) The daily production is assumed to be 80 barrels for oil and 600Mcf for natural gas and the price as $\$ 95 /$ barrel and $\$ 4.22 / M c f$, which are rough averages of the past year up to July. Price variation will affect METRR differently in these three jurisdictions: (1) Alberta's conventional and oil sands royalties is set to be price-sensitive and hence the higher the price, the higher the METRR, (2) Saskatchewan's royalty is based on production (albeit also price sensitive) and hence the higher the price, the slightly lower the METRR, and (3) the royalty regime in Newfoundland \& Labrador is ultimately proportional to net profit and hence its METRR is insensitive to price changes.

ii) Numbers shown in the Table are the average between oil and gas; for Saskatchewan, the calculations are for fourth-tier oil and gas. Saskatchewan also collects a resource surcharge from oil and gas companies.

iii) Assuming investment project has reached Tier 2 payout threshold. The provincial resource and manufacturing industries also benefit from the 10 percent Atlantic investment tax credit.

iv) Including agriculture, forestry, public utility, construction, manufacturing, wholesale and retail, communication, transportation, and other services. 
The federal government supports the removal of some of the subsidies to producers. In reference to the transition over five years for intangible capital expenses in oil sands mining projects from 100 percent deduction under the Canadian Exploration Expense provision of the Income Tax Act to 30 percent deduction under the Canadian Development Expense, the 2011 Budget notes:

\begin{abstract}
"These changes will help ensure that investment decisions are based on market factors rather than income tax treatment, subject to applicable regulations. To the extent that these changes remove incentives that may contribute to a higher level of investment than would otherwise have occurred, they could contribute indirectly to goals in the Federal Sustainable Development Strategy relating to reducing emissions of greenhouse gases and minimizing threats to air quality, protecting water quality, and conserving ecosystems and habitat." ${ }^{36}$
\end{abstract}

\title{
MISSED OPPORTUNITIES PROVIDE FOR FUTURE DIRECTIONS
}

Previous federal budgets have missed opportunities to greatly enhance and protect Canada's natural capital and hence ensure its goods and services continue to support a sustainable economy and environment. But they also illustrate directions the federal government (and, where applicable, provincial governments) could take to put Canada on track to a lower carbon economy in which its ecosystem goods and services are fully valued. ${ }^{37}$ The following areas for change emerge from the assessment above:

- Previous budgets have announced the phase-out of some existing subsidies (e.g., 100 percent ACCA for oil sand capital assets) and set explicit end dates for a number of energy efficiency programs. I fully support these directions, but argue that we could move more quickly to phase out subsidies where warranted and expand the list to cover other forms of federal subsidy to the energy sector, whether that energy is from fossil fuels or renewable sources. The key to efficiency is to have prices that reflect the costs of production plus any environmental costs and other externalities. Studies of the efficiency losses due to subsidies abound in the literature. ${ }^{38}$ Subsidies keep prices lower than their market-clearing level or generate rents for producers. Lower prices encourage energy consumption, thus removing subsidies can improve environmental quality (and in principle then, have similar effects to

36 Government of Canada (2011) Budget. P. 312.

37 It is beyond the scope of this paper to also address the issue of how energy prices would be affected if full-cost pricing of environmental impacts of extraction and use were incorporated in addition to the impact of the removal of subsidies. Suffice it to say that the prices of fuels that are more pollution-intensive and lead to greater environmental degradation would rise significantly and contribute to the more rapid diffusion of less pollution intensive energy sources. See, for example, Hohmeyer, O. (1992) "Renewables and the Full Costs of Energy," Energy Policy 20(4): 365-375 and Schilling, M. and M. Esmundo (2009) "Technology S-Curves and Renewable Energy Alternatives: Analysis and Implications for Government," Energy Policy 37(5): 1767-1781. Removal of subsidies is a step in the direction of full-cost pricing.

38 See, for example, IEA, OPEC, OECD, World Bank (2010). "Subsidies and Suggestions for the G-20 Initiative," Joint Report prepared for submission to the G-20 Summit Meeting, Toronto, Canada, 26-27 June 2010, 16 June 2010. Accessed at: http://www.iea.org/weo/docs/G20_Subsidy_Joint_Report.pdf, November 10, 2011 and Larson, B. and A. Shah (1992) "World Fossil Fuel Subsidies and Global Carbon Emissions," Background Paper for World Development Report, 1992. 
the introduction of a tax on the energy source). As a general principle, there is no longer a need to sustain subsidies of any form to non-renewable energy production. Doing so creates distortions in the tax system and inhibits the government's goal of tax neutrality across sectors. In the Leaders' Statement from the 2009 G-20 meeting, item 24 captures the essence of the argument with their agreement.... "[T]o phase out over the medium term inefficient fossil fuel subsidies while providing targeted support for the poorest. Inefficient fossil fuel subsidies encourage wasteful consumption, reduce our energy security, impede investment in clean energy sources and undermine efforts to deal with the threat of climate change. ${ }^{39}$ Reduction in subsidies can help reach environmental targets. Candidates for phase-out include ACCA for exploration and development, and tax depreciation rates for oil sands leases and building mines. It is difficult to come up with good estimates of the foregone tax revenue that would be regained once the subsidies are eliminated. As noted above, the combined effect of federal and provincial tax/royalty systems needs to be assessed in the context of economic decision-making. Nonetheless, there is the potential for substantial revenue gain to assist the government in meeting its deficit targets or for use in paying for other programs that would enhance natural capital if subsidies where METRs below that of the benchmark economy are phased out.

- While many of the subsidies to renewable energy production are at the provincial level and hence beyond the scope of this paper, there is little compelling rationale for the continuation of subsidies to biofuels such as corn ethanol and many other renewable energy sources at any level of government. Existing programs should be phased out over the next few years. I argued above that subsidies to consumers for energy-efficient investments are fraught with challenges and as such, most should not be continued. There are better ways to improve energy efficiency (e.g., at the provincial level with building codes and standards, at the federal level with energy efficiency standards for appliances). Low-income Canadians could be assisted by other types of programs, for example, low-interest loans for energyefficient purchases, rather than subsidies that are universally available to all income levels. Another candidate for phase out is the tax subsidy for those holding transit passes.

- The Gas Tax Fund appears to have a number of successful investments in environmental infrastructure. What is missing is a fund to support investments that help pay for ecosystem goods and services that are not captured by the market. These include payments to landowners to enhance natural capital on their farms and ranches, or in other privately held natural areas. The government has committed to increase the number and coverage of protected areas (land and marine), but these cover public lands, not private. Threats to natural capital are intense in settled areas of Canada and governments at the provincial and local level simply do not have the resources to support what is known in the literature as payments for ecosystem services (PES). There are a number of organizations such as Ducks Unlimited, the Nature Conservancy and the federal departments of Agriculture and Environment that have developed and participated in PES programs. These have tended to be one-off pilot studies with temporary funding. A national PES program that uses an enriched reallocation of more of the federal fuel excise tax revenue (with revenue-sharing arrangements in the provinces) would be an exciting initiative that could pay off, by productive capacity of the economy and the quality of life. Similarly, municipalities are 39 http://www.canadainternational.gc.ca/g20/summit-sommet/g20/declaration_092509.aspx?view=d, accessed
November 15, 2011. 
ensuring sustained supplies of ecosystem goods and services that enhance both the grappling with how to provide transportation infrastructure (public transit) that gives people options other than use of their vehicle (particularly single-occupancy use) and reduces congestion that costs people and industry billions of dollars a year in time, fuel, and frustration. Current funding methods include gas taxes, parking fees, fares for public transit and government transfers (such as the GTF and those from provincial governments). There is growing interest in road pricing given its success in other countries and the advent of technology that makes a more complex system than cordon pricing possible. While these are provincial/municipal matters, the federal government could show leadership by cosponsoring with interested provinces and municipalities some pilot studies on road pricing in a sample of larger municipalities across Canada that were willing to participate in the study. Several large and successful pilot studies have been done in the United States that could serve as a basis for these pilots. ${ }^{40}$

- Virtually all energy consumed in Canada does not reflect the environmental costs associated with its production, distribution and consumption. Energy prices are either set on world markets as in the case of oil, by regulators as for electricity and natural gas in many provinces, or by local/regional markets (electricity in some provinces). Canada does not directly price pollution, GHGs or other deleterious attributes of energy production and consumption. Hence, the environmental cost of many forms of energy use exceeds its private cost, often by substantial amounts. ${ }^{41}$ The upshot is that prices for energy are relatively low in Canada because we have large endowments of energy sources, weak environmental regulation and virtually no environmental pricing. Investment in energy-saving technology would be boosted by pricing energy to reflect its environmental costs as well as private costs. The market system can help achieve environmental targets in a more efficient way than regulating emissions directly (where regulations impose implicit prices), especially when there are different ways to reduce emissions through different technologies, shifting input mixes or product lines. Carbon can be priced through a tax on emissions or creation of a market in carbon allowances. A national carbon tax, set initially at the level of the 2012 BC carbon tax ( $\$ 30$ per tonne $\mathrm{CO}_{2} \mathrm{e}$ ) is the most efficient way to price carbon, as a growing number of industry leaders argue. Delay in enacting policies to achieve significant reduction in GHG emissions increases the total costs of reaching GHG targets, in some estimates by a factor of four. In other words, by not investing a dollar today in reducing GHGs, it may cost more than $\$ 4$ in 2020 due to the increase in emissions over the interim. We seek balanced budgets to avoid taxing the future for our expenditures today; the principle of pricing carbon today is identical. Technological advancements to reduce carbon emissions or prevent them from reaching the atmosphere are also going to be needed, but spending billions of dollars on, for example, carbon capture and storage, and not pricing carbon today is risky, in that these technologies might not work and cost the economy far more than letting the market respond in the most efficient way when GHGs are priced. Similar arguments apply to other forms of environmental contaminants to air, water, and land.

40 See, for example, Hanley, P. and J. Kuhl (2011) "National Evaluation of a Mileage-Based Road User Charge: Initial Results," unpublished paper and Robitalle, M. Methipara, J. and L. Zhang (2010) "Effectiveness and Equity of a Vehicle Mileage Fee at the Federal and State Levels," unpublished paper.

${ }^{41}$ Much of the work on the environmental costs of energy production and use have been done in Europe, in part because a number of European countries have moved closer to full-cost pricing through environmental taxation and other policies. See, for example, the European Commission's ExternE website, http://www.externe.info/, that describes methodologies for estimating environmental costs and provides calculations for energy fuels. An example for biofuels is Hill et al. (2006) "Environmental, Economic, and Energetic Costs and Benefits of Biodiesel and Ethanol Biofuels" PNAS [Proceedings of the National Academy of Science] 103(30): 11206-11210. There is vast literature on the costs of climate change (e.g., the Stern Report) as well as costs of air pollution from point sources such as coal-fired generation of electricity. 
A final thought that warrants more research and analysis than possible in this paper is that the use of full-cost pricing could assist the federal government in reducing the regulatory burden of the review process for major investment projects. Full-cost pricing could be one of the components of potential changes to federal acts now under review that govern projects that impact natural capital (e.g., Canadian Environmental Assessment Act, Fisheries Act, Species at Risk Act). One idea for full-cost pricing would be to require proponents of major projects to incorporate in the project submissions data on the full costs of projects that can be verified by independent sources, such as the Commissioner for the Environment and Sustainable Development. Another potential application of full-cost pricing would be to require proponents to post a refundable environmental bond that incorporates the risk to the environment of deleterious impacts.

In conclusion, three policy directions - phasing out subsidies; investing in natural capital and its ecosystem goods and services, and full-cost pricing of energy - can form the foundations of an environmental policy direction in upcoming budgets that will move the country closer to achieving the goals of a clean and healthy environment with an efficient and productive economy. Without a healthy natural environment, there is no healthy economy. Protecting Canada's natural capital is investing in our future, not creating deficits that saddle our children and grandchildren with a large debt that they may not be able to repay. 


\section{REFERENCES}

Auld, D. (2008). "The Ethanol Trap: Why Policies to Promote Ethanol as Fuel Need Rethinking," C.D. Howe Commentary No. 268, July 2008.

Boyd, J. and S. Banzhaf (2006). "What are Ecosystem Services? The Need for Standardized Environmental Accounting Units" Resources for the Future, RFF Discussion Paper 06-02, January 2006. Washington, DC.

Budget 2010. "Leading the Way on Jobs and Growth". March 4, 2010.

Carlson et al. (2000). "SO2 Control by Electric Utilities: What are the Gains from Trade?" Journal of Political Economy, Vol. 108, No. 6: 1292-1326.

Commission on the Reform of Ontario's Public Services (2012). "Public Services for Ontarians: A Path to Sustainability and Excellence". (Drummond Report). Queen's Printer for Ontario. Accessed at: http://www.fin.gov.on.ca/en/reformcommission/chapters/report.pdf, on 22 February 2012.

Ellerman, A.D. (2003). "Ex Post Evaluation of Tradable Permits: The U.S. SO2 Cap-and-Trade Program" Center for Energy and Environmental Policy Research, MIT, 03-003 Working Paper, February 2003.

Government of Canada (2011) "The Next Phase of Canada's Economic Action Plan, A Low-Tax Plan for Jobs and Growth,” June 6, 2011. Accessed at www.fin.gc.ca.

EIA, US Energy Information Agency (2007). "Biofuels in the U.S. Transportation Sector", http://www.eia.gov/oiaf/analysispaper/pdf/tbl12.pdf, accessed 23 February 2012.

Eto J., Kito S., Shown L., Sonnenblick, R. (2000). "Where did the Money Go? The Cost and Performance of the Largest Commercial Sector DSM Programs," Energy Journal 21(2):23.

Freeman, A.M. (2003). The Measurement of Environmental and Resource Values. Washington, DC: Resources for the Future.

Government of Canada (2007, 2008, 2009, 2010, 2011) Budget.

Green Budget Coalition (2011) "Preliminary Recommendations for Budget 2012," http://www.greenbudget.ca/2012/prelim.html accessed on November 15, 2012.

Hanley, P. and J. Kuhl (2011). "National Evaluation of a Mileage-Based Road User Charge: Initial Results", unpublished paper.

Harchaoui, T.M. and P. Lasserre. 2002. Assessing the Impact of Greenhouse Gas Emissions on Canada's Productivity Growth, 1981-1996 - An Experimental Approach. Economic Analysis Research Paper Series 11F0027MIE2002009. Analytical Studies Branch. Ottawa: Statistics Canada.

Hill, J. et al. (2006). "Environmental, Economic, and Energetic Costs and Benefits of Biodiesel and Ethanol Biofuels" PNAS [Proceedings of the National Academy of Science] 103(30): 11206-11210.

Hohmeyer, O. (1992). "Renewables and the Full Costs of Energy" Energy Policy 20(4): 365-375.

IEA, OPEC, OECD, World Bank (2010). "Subsidies and Suggestions for the G-20 Initiative," Joint Report prepared for submission to the G-20 Summit Meeting, Toronto, Canada, 26-27 June 2010, 16 June 2010. Accessed at: http://www.iea.org/weo/docs/G20_Subsidy_Joint_Report.pdf, November 10, 2011.

Larson, B. and A. Shah (1992) "World Fossil Fuel Subsidies and Global Carbon Emissions," Background Paper for World Development Report, 1992. 
Malm E. (1996). "An Actions-based Estimate of the Free Rider Fraction in Electric Utility DSM Programs," Energy Journal 17(3):41.

Manzzanti, M. and R. Zoboli (2007). "Environmental Efficiency, Emission Trends and Labour Productivity: Trade-Off or Joint Dynamics? Empirical Evidence Using NAMEA Panel Data". Italy: The Fondazione Eni Enrico Mattei Note di Lavoro Series Index, Nota Di Lavoro 40.2007 April 2007. Accessed at: http://ageconsearch.umn.edu/bitstream/9320/1/wp070040.pdf, February 23, 2012.

Mintz, J. and N. Olewiler (2008). "A Simple Approach for Bettering the Environment and Economy: Restructuring the Federal Fuel Excise Tax." Ottawa: Sustainable Prosperity.

National Research Council (2004). Valuing Ecosystem Services: Toward Better Environmental Decision Making. Washington, DC: National Academy of Sciences.

National Round Table on the Environment and the Economy (2009). Achieving 2050: A Carbon Pricing Policy for Canada. Ottawa, ON: Government of Canada.

Natural Resources Canada (2009). "Improving Energy Performance in Canada," Report to Parliament under the Energy Efficiency Act for the Fiscal Year, 2007-2008.

Olewiler, N. (2004). "The Value of Natural Capital in Settled Areas of Canada" Ducks Unlimited Canada and The Nature Conservancy of Canada.

Ostblom, G. And E. Samakovlis (2004). "Costs of Climate Policy when Pollution Affects Health and Productivity, A General Equilibrium Analysis applied to Sweden”. Stockholm: National Institute of Economic Research, Working Paper No. 93, December 2004. Accessed at: http://konj.se/download/18.70c52033121865b13988000100744/WP_93.pdf, 24 February 2012.

Report of the Treasury Board of Canada (2010) Canada's Performance 2009-2010, Government of Canada's Contribution. Accessed at: http://www.tbs-sct.gc.ca/reports-rapports/cp-rc/2009-2010/cp-rctxt-eng.asp\#clean, on 12 November 2011.

Robitalle, M. Methipara, J. and L. Zhang (2010). "Effectiveness and Equity of a Vehicle Mileage Fee at the Federal and State Levels". Unpublished paper.

Schilling, M. and M. Esmundo (2009). “Technology S-Curves and Renewable Energy Alternatives: Analysis and Implications for Government” Energy Policy 37(5): 1767-1781.

Stern, N. (2006) The Economics of Climate Change. UK: HM Treasury.

TEEB (2010) "The Economics of Ecosystems and Biodiversity: Mainstreaming the Economics of Nature: A synthesis of the approach, conclusions and recommendations of TEEB." Hosted by the United Nations Environment Program.

Transport Canada (2011). "Evaluation of the Clean Transportation Theme of the Clean Air Agenda," July 2011. Accessed at http://www.tc.gc.ca/eng/corporate-services/des-reports-829.htm on November 12, 2011.

Zivin, J. and M. Neidell (2011). "The Impact of Pollution on Worker Productivity", National Bureau of Economic Research Working Paper 17004. Accessed at http://www.nber.org/papers/w17004 on February $22,2012$. 


\section{ABOUT THIS PUBLICATION}

The School of Public Policy Research Papers provide in-depth, evidence-based assessments and recommendations on a range of public policy issues. Research Papers are put through a stringent peer review process prior to being made available to academics, policy makers, the media and the public at large. Views expressed in The School of Public Policy Research Papers are the opinions of the author(s) and do not necessarily represent the view of The School of Public Policy.

\section{OUR MANDATE}

The University of Calgary is home to scholars in 16 faculties (offering more than 80 academic programs) and 36 Research Institutes and Centres including The School of Public Policy. Under the direction of Jack Mintz, Palmer Chair in Public Policy, and supported by more than 100 academics and researchers, the work of The School of Public Policy and its students contributes to a more meaningful and informed public debate on fiscal, social, energy, environmental and international issues to improve Canada's and Alberta's economic and social performance.

The School of Public Policy achieves its objectives through fostering ongoing partnerships with federal, provincial, state and municipal governments, industry associations, NGOs, and leading academic institutions internationally. Foreign Investment Advisory Committee of the World Bank, International Monetary Fund, Finance Canada, Department of Foreign Affairs and International Trade Canada, and Government of Alberta, are just some of the partners already engaged with the School's activities.

For those in government, The School of Public Policy helps to build capacity and assists in the training of public servants through degree and non-degree programs that are critical for an effective public service in Canada. For those outside of the public sector, its programs enhance the effectiveness of public policy, providing a better understanding of the objectives and limitations faced by governments in the application of legislation.

\section{DISTRIBUTION}

Our publications are available online at www.policyschool.ca.

\section{DISCLAIMER}

The opinions expressed in these publications are the authors' alone and therefore do not necessarily reflect the opinions of the supporters, staff, or boards of The School of Public Policy.

\section{COPYRIGHT}

Copyright (C 2012 by The School of Public Policy.

All rights reserved. No part of this publication may be reproduced in any manner whatsoever without written permission except in the case of brief passages quoted in critical articles and reviews.

\section{ISSN}

1919-112x SPP Research Papers (Print) 1919-1138 SPP Research Papers (Online)

\section{DATE OF ISSUE}

March 2012

\section{MEDIA INQUIRIES AND INFORMATION}

For media inquiries, please contact Morten Paulsen at 403-453-0062.

Our web site, www.policyschool.ca, contains more information about The School's events, publications, and staff.

\section{DEVELOPMENT}

For information about contributing to The School of Public Policy, please contact Candice Naylen by telephone at 403-210-7099 or by e-mail at cnaylen@ucalgary.ca.

\section{EDITOR}

Timothy Giannuzzi
Sponsored by

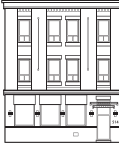

\section{MANNING FOUNDATION}




\section{RECENT PUBLICATIONS BY THE SCHOOL OF PUBLIC POLICY}

DEPARTURES FROM NEUTRALITY IN CANADA'S GOODS AND SERVICES TAX

http:// policyschool.ucalgary.ca/?q=content/ departures-neutrality-canadas-goods-and-services-tax.pdf Michael Smart | February 2012

SOME OBSERVATIONS ON THE CONCEPT AND MEASUREMENT OF INCOME INEQUALITY http:// policyschool.ucalgary.ca/sites/default/files/research/richardson-comm2.pdf Stephen R. Richardson | February 2012

A REVIEW AND ASSESSMENT OF PRIVATIZATON IN CANADA

http:/ / policyschool.ucalgary.ca/sites/default/files/research/boardman-vining-privatization.pdf Anthony E. Boardman and Aidan R. Vining | January 2012

THE INTERNATIONAL EXPERIENCE WITH PRIVATIZATION: ITS RAPID RISE, PARTIAL FALL AND UNCERTAIN FUTURE

http:// policyschool.ucalgary.ca/ sites/default/files/research/nellis-privatization.pdf

John Nellis | January 2012

HOUSING SUBSIDIES AND HOMELESSNESS: A SIMPLE IDEA

http:/ / policyschool.ucalgary.ca/sites/default/files/research/oflaherty-housing-subsidy.pdf

Brendan O'Flaherty | January 2012

PUBLIC SECTOR WAGE GROWTH IN ALBERTA

http:/ / policyschool.ucalgary.ca/sites/default/ files/research/boesenkool-public-wage-growth.pdf Ken Boessenkool and Ben Eisen | January 2012

CATCHING THE BRASS RING: OIL MARKET DIVERSIFICATION POTENTIAL FOR CANADA http:/ / policyschool.ucalgary.ca/ sites/default/ files/research/mmoore-oilmarket.pdf M.C. Moore, S. Flaim, D. Hackett, S. Grissom, D. Crisan and A. Honarvar | December 2011

THE CONSTITUTIONALITY OF FEDERAL CLIMATE CHANGE LEGISLATION

http:/ / policyschool.ucalgary.ca/ ?q=content/constitutionality-federal-climate-change-legislation

Alastair Lucas and Jenette Yearsley | December 2011

THE MYTHS AND FACTS OF FOSSIL FUEL SUBSIDIES: A CRITIQUE OF EXISTING STUDIES

http:/ / policyschool.ucalgary.ca/files/ public policy/MCKENZIE\%20MINTZ\%20online.pdf

Kenneth J. McKenzie and Jack M. Mintz | October 2011

HOMELESSNESS IN ALBERTA: THE DEMAND FOR SPACES IN ALBERTA'S HOMELESS SHELTERS

http:/ / policyschool.ucalgary.ca/files/ publicpolicy/ homelessness\%20in\%20alberta.pdf

Ronald Kneebone, J.C. Herbert Emery and Oksana Grynishak | September 2011

THE NEW SECURITY PERIMETER WITH THE UNITED STATES

http:/ / policyschool.ucalgary.ca/files/ publicpolicy/flemming\%20sept011.pdf

Brian Flemming | September 2011

INCOME SUPPORT FOR PERSONS WITH DISABILITIES

http:// policyschool.ucalgary.ca/files/public policy/Kneebone_Disability_Study.pdf

Ronald Kneebone and Oksana Grynishak | September 2011

INVESTMENT REVIEW IN CANADA - WE CAN DO BETTER

http:/ / policyschool.ucalgary.ca/files/publicpolicy/Herman\%20Invest\%20Canada\%20online.pdf

Lawrence L. Herman | September 2011 